\title{
Tropospheric distribution of sulphate aerosols mass and number concentration during INDOEX-IFP and its transport over the Indian Ocean: a GCM study
}

\author{
S. Verma ${ }^{1, *}$, O. Boucher ${ }^{2}$, M. Shekar Reddy ${ }^{2}$, H. C. Upadhyaya ${ }^{1}$, P. Le Van ${ }^{3}$, F. S. Binkowski ${ }^{4}$, and O. P. Sharma ${ }^{1}$ \\ ${ }^{1}$ Centre for Atmospheric Sciences, Indian Institute of Technology Delhi, New Delhi, India \\ ${ }^{2}$ Laboratoire d'Optique Atmosphérique, CNRS/Université des Sciences et Technologies de Lille, 59655 Villeneuve d'Ascq \\ Cedex, France \\ ${ }^{3}$ Laboratoire de Météorologie Dynamique Ecole Normale Supérieure, 24 rue Lhomond, 75231 Paris Cedex 05, France \\ ${ }^{4}$ Environmental Science and Engineering, University of North Carolina, Chapel Hill, USA \\ *now at: Centre of Excellence in Climatology, Birla Institute of Technology (BIT) Mesra, Extn Centre Jaipur, Rajasthan, India
}

Correspondence to: S. Verma (verma.sunita@gmail.com)

Received: 11 October 2004 - Published in Atmos. Chem. Phys. Discuss.: 31 January 2005

Revised: 14 June 2012 - Accepted: 23 June 2012 - Published: 18 July 2012

\begin{abstract}
The sulphate aerosols mass and number concentration during the Indian Ocean Experiment (INDOEX) Intensive Field Phase-1999 (INDOEX-IFP) has been simulated using an interactive chemistry GCM. The model considers an interactive scheme for feedback from chemistry to meteorology with internally resolving microphysical properties of aerosols. In particular, the interactive scheme has the ability to predict both particle mass and number concentration for the Aitken and accumulation modes as prognostic variables.

On the basis of size distribution retrieved from the observations made along the cruise route during IFP-1999, the model successfully simulates the order of magnitude of aerosol number concentration. The results show the southward migration of minimum concentrations, which follows ITCZ (Inter Tropical Convergence Zone) migration. Sulphate surface concentration during INDOEX-IFP at Kaashidhoo $\left(73.46^{\circ} \mathrm{E}, 4.96^{\circ} \mathrm{N}\right)$ gives an agreement within a factor of 2 to 3 . The measured aerosol optical depth (AOD) from all aerosol species at $\mathrm{KCO}$ was $0.37 \pm 0.11$ while the model simulated sulphate AOD ranged from 0.05 to 0.11 . As sulphate constitutes $29 \%$ of the observed AOD, the model predicted values of sulphate AOD are hence fairly close to the measured values. The model thus has capability to predict the vertically integrated column sulphate burden. Furthermore, the model results indicate that Indian contribution to the estimated sulphate burden over India is more than $60 \%$ with values upto $40 \%$ over the Arabian Sea.
\end{abstract}

\section{Introduction}

The aerosol effects on climate can be large and complex due to the fact that aerosols chemical composition, abundance and size distribution are highly variable, both spatially and temporally. Most of the earliest investigations on direct aerosol forcing have focused on sulphate aerosols because of their importance as an anthropogenic aerosol component (Charlson et al., 1992; Kiehl and Briegleb, 1993). Sulphate particle is an important component of atmospheric aerosols. Sulphate make up a substantial fraction of tropospheric aerosol in both urban and remote/rural areas (Barth and Church, 1999; Ramanathan et al., 2001; Mallet et al., 2004). Sulphate aerosols are capable of modifying the climate not only by scattering incoming sunlight back to space (direct effect) but also by altering the properties of clouds (indirect effect). In order to further understand sulphate aerosolclimate interactions, the present study is carried out with the Laboratoire de Météorologie Dynamique interactive chemistry global model (Verma et al., 2007) to produce the simulation of INDOEX-IFP. The three fundamental objectives of this study are

1. to simulate sulphate aerosol dynamics as prognostic variables, 
2. to compare and evaluate model-derived physical, optical, and radiative properties of sulphate aerosols with observations during INDOEX-IFP,

3. to examine sulphate aerosol transport and radiative forcing, and the contribution of Indian emissions to the regional burden using the emission inventory developed by Reddy and Venkataraman (2002a, b).

INDOEX was conducted during the winter monsoon season, when pristine air-mass from the Southern Hemisphere and not-so-clean air from the Indian subcontinent meet over the tropical Indian Ocean and provide a natural laboratory for studying aerosol influences. Primarily, its goal was to assess the natural and anthropogenic climate forcing due to aerosols and to examine the underlying feedback mechanisms on scales relevant to regional and global climate. Ramanathan et al. (2001) have presented the INDOEX results for the oceanic regions adjacent to the Indian subcontinent, which reveal the presence of a dense anthropogenic aerosol layer over China, South and Southeast Asia. While INDOEX suggests south/southeast Asia as the regions of major sources of aerosols for the Indian Ocean, the controversy still persists regarding the formation, movement, persistence and effects of this regional haze on the regional and global climate, e.g. the South Asian Atmospheric Brown Cloud (UNEP and $\left.C^{4}, 2002\right)$. In order to address such high priority issues of concern to climate, this study, in logical continuation of earlier studies (Krishnamurti et al. 1998; Rajeev et al., 2000; Satheesh and Ramanathan, 2000; Verver et al., 2001; Rasch et al. 2001; Ramanathan et al. 2001; Andronache et al. 2002; Lawrence and Lelieveld 2010 and references therein), deals with the INDOEX region. The main motivation of this study is to reproduce the observed variations in the sulphate aerosol mass and number concentration during the Indian Ocean Experiment from January to March 1999 using LMD interactive chemisry GCM.

The present model uses a comprehensive numerical scheme to deal with the gas-phase and aqueous-phase reactions in a GCM, where the concentrations of radicals like $\mathrm{OH}, \mathrm{HO}_{2}$ and gases like $\mathrm{O}_{3}, \mathrm{H}_{2} \mathrm{O}_{2}, \mathrm{NH}_{3}$ and $\mathrm{NO}_{\mathrm{x}}$ are computed within the zoom version of LMD-ZT GCM. The sulphate aerosol/chemistry is interactively included in the model. The model considers both sulphur mass and number concentrations as a truly interactive part and not merely a passive component in atmospheric chemistry (Verma et al., 2007). The knowledge of the sulphate aerosol number concentration is important to understand the indirect radiative forcing of the aerosols and to refine estimates of the direct radiative forcing.

The model design therefore differs from the earlier studies of Lawrence et al. (1999), Rasch et al. (2000), Boucher et al. (2002), Hauglustaine et al. (2004), Vignati et al. (2004) and Stier et al. (2005) which employ analyzed meteorology/observations or prescribed three-dimensional short lived radical fields to drive the CTM. The experiments are de- signed to assess impacts of sulphate aerosols on INDOEX region.

\section{Model description}

\subsection{The atmospheric global model}

The LMDZ is a development of previous LMD model described by Sadourny and Laval (1984), which was utilised along with other global models of major meteorological centres, to achieve the AMIP I objective of atmospheric model intercomparison (Boer, 1992; Cess et al., 1989) and also to carry out long-term simulations for certain climate and aerosol studies (Le Treut et al., 1994; Boucher and Lohmann, 1995; Sharma et al., 1998; Boucher et al., 1998; Boucher et al., 2002 etc). The LMDZ has the capability to zoom with a finer resolution over a specific region of interest over the globe and relatively a coarser resolution over rest of the globe, which gives a unique opportunity to study the regional aspects of aerosols. The model solves the primitive equations of meteorology and mass continuity for sixteen tracers. The discrete analogues of the dynamical equations are obtained using finite difference formulations on Arakawa-C grid and the physical package of the model includes a set of parameterisations for convection, radiative transfer, planetary boundary layer (PBL), gravity wave drag and ground hydrology with no vegetation. For a complete description of the atmospheric model dynamics and physical parameterisation of physical processes one may refer to Sadourny and Laval (1984), Le Treut et al. (1994) and Hourdin and Armengaud (1999). The climatology of this model has been presented by Li (1999) and Lott (1999). An important addition to LMDZ in the version used here is the inclusion of a prognostic sulphur-cycle scheme (Verma et al., 2007). In particular, the model considers an interactive scheme for feedback from chemistry to meteorology with internally resolving microphysical properties of aerosols for radiative transfer computations. Thus, it is a step towards correcting the deficiencies where the microphysics and feedbacks are run offline. Except for some parameterisations, it should be noted that the chemistry module has been developed independently from that of Boucher et al. (2002) and Hauglustaine et al. (2004).

\subsection{Chemistry and aerosol modules}

The chemistry module includes natural and anthropogenic emissions, treatment of sulphur and nitrogen sources, their chemical transformations and deposition processes (Verma et al., 2007). The basic chemistry module consists of over 50 gas/aqueous phase chemical reactions (33 gas phase and 18 aqueous phase) along with the sources and sinks of chemical species. The prognostic chemical species in the LMDZ model are water vapour, liquid water, dimethylsulphide (DMS), hydrogensulphide $\left(\mathrm{H}_{2} \mathrm{~S}\right)$, dimethylsulphoxide 


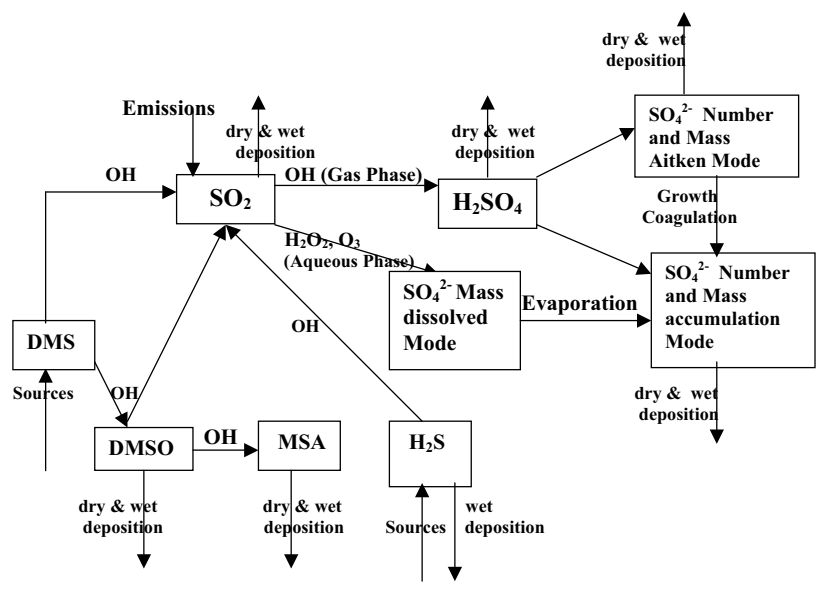

Fig. 1. The schematic representation of the sulphur module in the LMDZ.

(DMSO), methanesulphonic acid (MSA), sulphur dioxide $\left(\mathrm{SO}_{2}\right)$, oxides of nitrogen $\left(\mathrm{NO}_{\mathrm{x}}\right)$, nitric acid $\left(\mathrm{HNO}_{3}\right)$, carbon monoxide $(\mathrm{CO})$, ozone $\left(\mathrm{O}_{3}\right)$, hydrogen peroxide $\left(\mathrm{H}_{2} \mathrm{O}_{2}\right)$ and sulphate aerosol mass and number for Aitken $(0.005-0.1 \mu \mathrm{m})$ and accumulation modes $(0.1-2.5 \mu \mathrm{m})$. The gas phase concentrations of $\mathrm{SO}_{2}, \mathrm{H}_{2} \mathrm{O}_{2}$ and $\mathrm{O}_{3}$ are estimated in the cloud phase assuming Henry's law and used to calculate the amount of sulphate formed in the cloudy regions (Schwartz, 1986). The model does not explicitly take into account mass transfer rates between the gas and the aqueous phase in view of an examination on mass transfer effect by Schwartz (1986) and Venkataraman et al. (2001) who have shown that the mass transfer effect does not limit the rate of sulphate formation.

The present approach utilises sulphuric acid produced in the gas phase as an input to the two-mode, two-moment aerosol module (Binkowski and Shankar, 1995) which calculates aerosol mass, number concentration and particle surface area for the Aitken and accumulation modes. The vapour sulphuric acid produced by gas phase oxidation is split into two parts: one going into Aitken and the other one condensing onto the existing particles (accumulation mode). The sulphate produced by aqueous phase oxidation remains dissolved in cloud droplets. However, when the clouds disappear, the sulphate in the dissolved state is added to the accumulation mode mass. Therefore all new sulphate mass produced by aqueous production is added to the accumulation mode but the number of accumulation mode particles remains unchanged (Fig. 1). The model represents a simplified version of the aqueous model of Walcek and Taylor (1986) and is similar to an earlier equilibrium model of Ohta et al. (1981). The equations for chemical equilibrium of the $\mathrm{SO}_{2}-\mathrm{NH}_{3}-\mathrm{CO}_{2}-\mathrm{HNO}_{3}-\mathrm{H}_{2} \mathrm{O}$ system are those from Chen and Crutzen (1994).

The mass fluxes, simulated by the Tiedtke (1989) scheme, are used to parameterise convective transport of gases and (a)

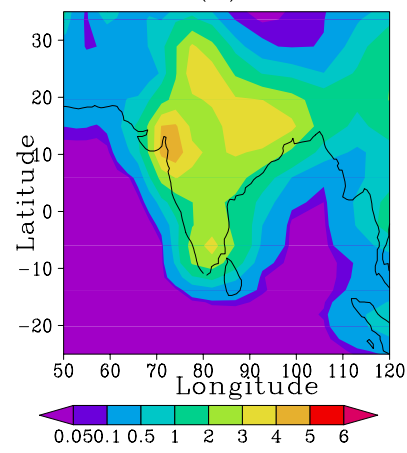

(b)

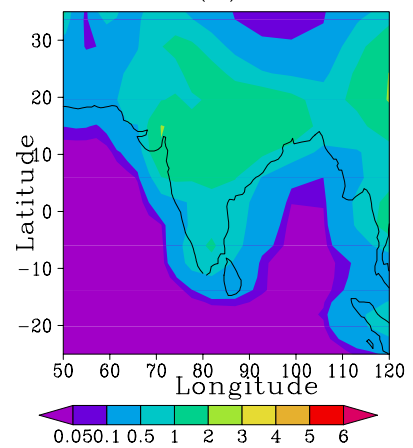

Fig. 2. The simulated $\mathrm{SO}_{2}$ emissions in the (a) $\mathrm{RV}$ and (b) GEIA inventories averaged for the INDOEX-IFP period $\left(10^{5} \mathrm{mg} \mathrm{S} \mathrm{m}^{-2} \mathrm{~s}^{-1}\right)$.

aerosols. Vertical transport of trace species is incorporated in updrafts and downdrafts, accounting for entrainment and detrainment. All chemical species along with aerosol mass and number concentration in the two modes are advected in the model. These species evolve consistently with dynamical, physical, cloud and chemical processes as the model state integrates forward with each time step. Convective transport is performed after wet scavenging calculation, in order to avoid upward transport of material that is scavenged by precipitation.

Dry deposition is parameterised through deposition velocities, which are prescribed for each chemical species and surface types. The model uses a simple parameterisation scheme, which assumes that the rate of deposition at the surface is directly proportional to the mixing ratio (i.e. concentration) of the respective species in the lowest model layer. To account for the effect of clouds in the grid box, the clear sky photolytic rates are multiplied by a correction factor. The wet removal scheme considers both in-cloud and belowcloud scavenging in the model. Rainfall is computed at every time step in the GCM. Removal of gases and aerosols by rain was parameterised using the model generated precipitation formation rate following Giorgi and Chameides (1986).

The $\mathrm{CO}_{2}$ concentration is held constant $(370 \mathrm{ppm})$ throughout the model integration. Mie theory is employed to compute the optical properties with prescribed size distribution and refractive indices. Optical properties are computed over the entire shortwave spectrum $(0.25-4.0 \mu \mathrm{m})$ at 24 wavelengths and grouped into the two model wavebands as weighted averages with a typical spectral distribution of the incoming solar radiation flux at the surface (Verma et al., 2006). The physical, cloud and chemical processes considered in the present model are described in details in (Verma et al., 2007). 
Table 1. Global annual sulphur emissions in the model $\left(\mathrm{Tg} \mathrm{S} \mathrm{yr}^{-1}\right)$.

\begin{tabular}{lrrr}
\hline Source & $\begin{array}{r}\text { Global } \\
\text { Emission } \\
\text { (GEIA) }\end{array}$ & $\begin{array}{r}\text { Indian } \\
\text { Emission } \\
\text { (GEIA) }\end{array}$ & $\begin{array}{r}\text { Indian } \\
\text { Emission } \\
(\mathrm{RV})\end{array}$ \\
\hline Biomass Burning & 3.39 & 0.24 & 0.33 \\
Fossil-Fuel & 66.31 & 1.44 & 2.38 \\
Total & 70.30 & 1.68 & 2.71 \\
\hline
\end{tabular}

\subsection{Emissions}

Three $\mathrm{SO}_{2}$ scenarios, which differ over India only, are used in the present study,

i. SCN-GEIA: emissions given for India in the Global Emission Inventory Activity (GEIA) inventory,

ii. SCN-RV: emissions of Reddy and Venkataraman (2002a, b) inventory (RV) for India,

iii. SCN-zero: emission from all over the world except India (i.e. emissions over India are set to zero).

The global sulphur emissions in GEIA database include emissions from fossil fuels combustion and industrial processes. The biomass burning sulphur emissions are from Pham et al. (1995). A fixed 5\% of sulphur from combustion sources is assumed to be emitted directly as sulfuric acid gas and condenses immediately on ambient aerosol particles. The annual anthropogenic $\mathrm{SO}_{2}$ emissions (manmade) from fossil fuel combustion and industrial activities are $66.31 \mathrm{Tg} \mathrm{S} \mathrm{yr}^{-1}$ globally with a contribution from India of $1.44 \mathrm{Tg} \mathrm{S} \mathrm{yr}^{-1}$ which increases to $2.38 \mathrm{Tg} \mathrm{S} \mathrm{yr}^{-1}$ if $\mathrm{RV}$ inventory is used (Table 1). The simulated $\mathrm{SO}_{2}$ emissions in the RV and GEIA inventories averaged for the INDOEX-IFP period are shown in Fig. 2. The RV emission inventory is constructed with very high source resolution. The sulphur emissions are estimated using plant specific fuel combustion (Reddy and Venkataraman, 2002b). For biomass burning, the emission inventory for India is constructed from spatially resolved data sets, which results in $0.33 \mathrm{Tg} \mathrm{S} \mathrm{yr}^{-1}$ as projection of $\mathrm{SO}_{2}$ emission for the INDOEX period (1998-1999).

\section{Results}

\subsection{Numerical simulations}

The model simulations have been performed using 72 parallels between North and South Poles with 96 points on each parallel. There are 19 vertical levels and a basic time step of half an hour is used for the model physics and chemistry. For this study, the LMDZ was run in zoom mode over the INDOEX study domain $\left(25^{\circ} \mathrm{S}-35^{\circ} \mathrm{N}, 50-100^{\circ} \mathrm{E}\right)$ with a uniform resolution of $1.25^{\circ}$ in longitude and $1.25^{\circ}$ in latitude at best around the zoom centre $\left(60^{\circ} \mathrm{E}, 0^{\circ}\right)$. The model initial state is prepared from 20 December 1999 European Centre for Medium-Range Weather Forecast (ECMWF) analysis. The surface albedo, soil moisture and sea-ice were also specified from the ECMWF analysis.

\subsection{Model evaluation}

\subsubsection{The Kaashidhoo climate observatory}

The simulated sulphate concentrations at the surface are compared with measured concentrations during INDOEXIFP (February-March 1999) at Kaashidhoo Climate Observatory (KCO), Maldives in the Indian Ocean. KCO was established as a part of INDOEX in the island of Kaashidhoo $\left(4.965^{\circ} \mathrm{N}, 73.466^{\circ} \mathrm{E}\right)$ about $500 \mathrm{~km}$ southwest of the southern tip of India, where the aerosol chemical, radiative, and microphysical properties were continuously measured since February 1998. The observatory serves as a key platform in the Indian Ocean. The aerosol characteristics observed at this location, from December to March, include both aerosols transported from the continents to the ocean and naturally produced at the ocean surface. The concentrations and properties of aerosols depend on the prevailing meteorological conditions. During the winter monsoon, the air mass over KCO mostly (about $90 \%$ of the time) originates from India and South Asia (Krishnamurti et al., 1998).

Here we compare the simulated sulphate concentration with corresponding measured concentration at $\mathrm{KCO}$ during INDOEX-IFP (Fig. 3). Modelled surface sulphate concentrations agree with the measured values within a factor of $2-3$. The inventory developed by Reddy and Venkataraman $(\mathrm{RV})$ has fine resolution $(0.25 \times 0.25)$ with specific emission factors for Indian regions. The identification of large point sources in the RV inventory is an advantage over the global inventories, where the emissions are estimated at country level. The aerosol concentrations downwind of Indian subcontinent are sensitive to the geographical location of the emission sources over the sub-continent. Model simulation shows an increase in concentration in the month of February with RV inventory. This result is in general agreement with the meteorological conditions at $\mathrm{KCO}$ as most of the air mass during February originated from India in contrast to March when the air mass originated from East Asia (Verver et al., 2001) flows towards it. The resolution of RV inventory thus gives a better agreement of sulphate concentrations with measurements at $\mathrm{KCO}$.

In contrast to surface concentrations, aerosol optical depth (AOD) is a measure of the entire aerosol column. The measured AOD from all aerosol species averaged over IFP at $\mathrm{KCO}$ was $0.37 \pm 0.11$. Model simulated sulphate AOD at $\mathrm{KCO}$ ranged from 0.05 to 0.11 during the IFP period. The $\mathrm{KCO}$ aerosol measurements reveal that sulphate is responsible for $29 \%$ (Satheesh and Ramanathan, 2000; Satheesh et al., 1999) of the observed aerosol optical depth. Taking 


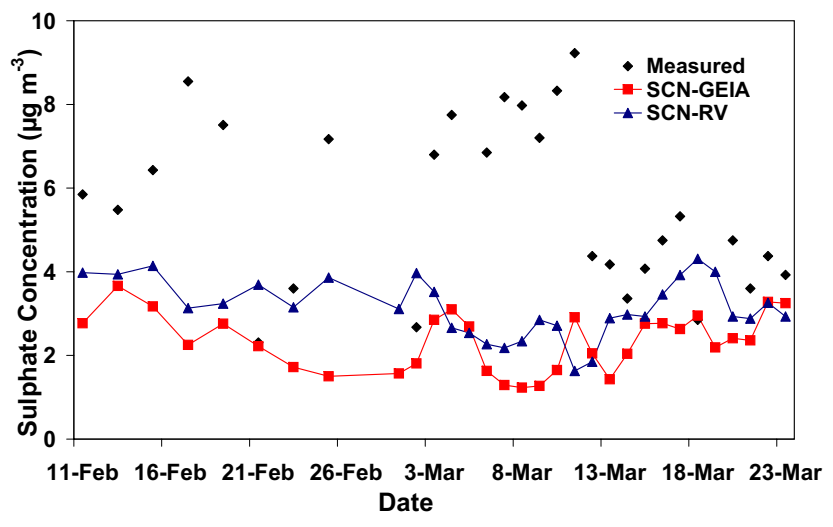

Fig. 3. Modelled (squares and triangles) and observed sulphate (diamonds) concentration at Kaashidhoo $\left[73.46^{\circ} \mathrm{E}, 4.96^{\circ} \mathrm{N}\right]$ during INDOEX-IFP.

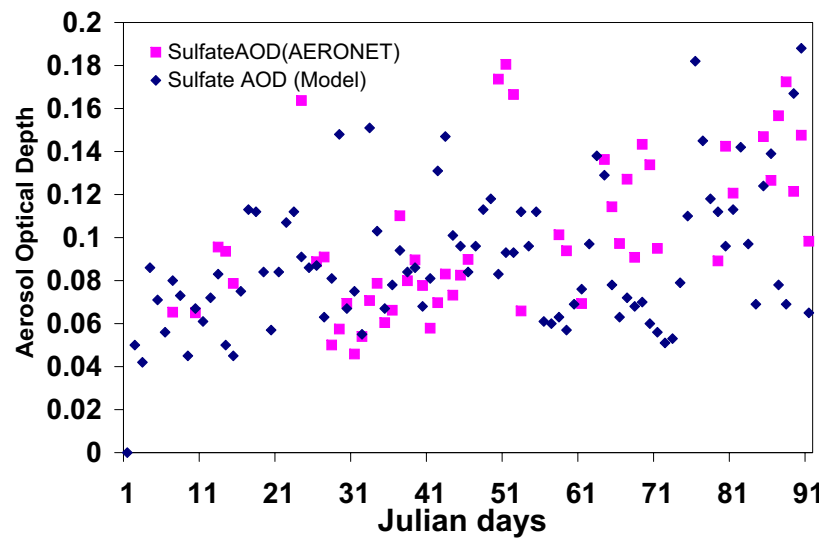

Fig. 4. Modelled and observed sulphate aerosol optical depth for the period January-March 1999 at Kaashidhoo [73.46 $\mathrm{E}$, 4.96 $\mathrm{N}$ ]. The observed AOD is obtained as $29 \%$ of the AERONET observed AOD. Note that rest of the figures are from SCN-RV except otherwise mentioned.

this fact into account, the model simulates the observed sulphate aerosol optical depth at KCO (Fig. 4) well. Further, to see the agreement of model simulated trace gases concentration to observations, we plot in Fig. 5 (upper panel) the $\mathrm{CO}$ surface concentration. The simulated $\mathrm{CO}$ concentration remarkably agrees with observations between day- 62 and day82 while the model underestimates the observations by a factor of 2 between day- 42 and day-62. Next, we plot simulated latitudinal ozone mixing ratios from $0-3 \mathrm{~km}$ altitude range. It is evident from Fig. 5 (lower panel) that model is able to simulate the general north-south gradient in the ozone concentration in lower troposphere (de Gouw et al., 2001). The model simulated ozone concentrations of 8 to $31 \mathrm{ppbv}$ agree well with the observed ozone profile ( 5 to $25 \mathrm{ppbv}$ ) obtained after averaging in the region lying between $8^{\circ} \mathrm{S}$ to $8^{\circ} \mathrm{N}$.
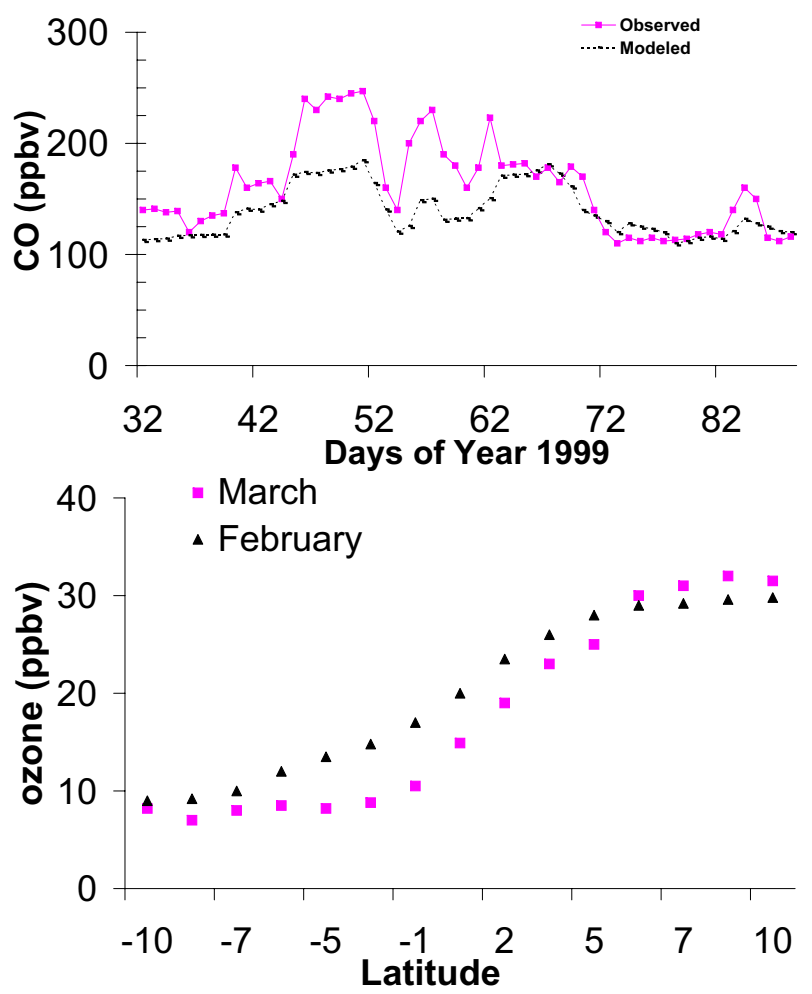

Fig. 5. Modelled and observed trace gas concentration of $\mathrm{CO}$ at $\mathrm{KCO}$ (upper panel) and simulated latitudinal ozone mixing ratios (lower panel).

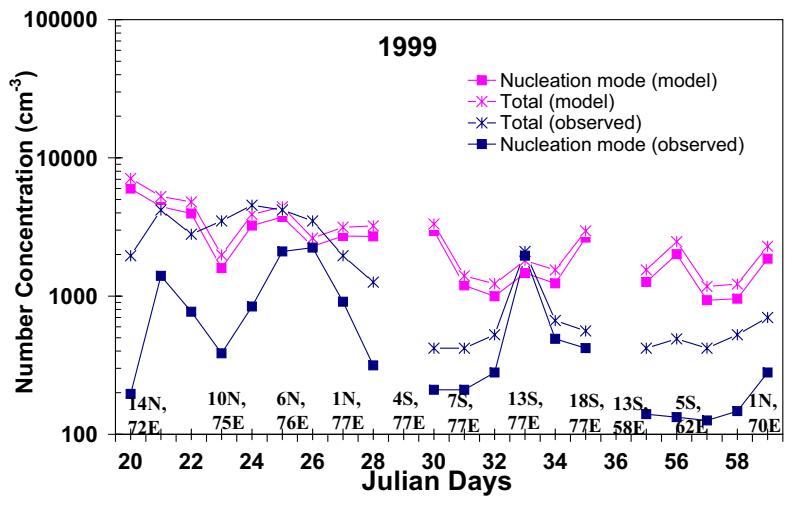

Fig. 6. Modelled and observed latitudinal variation of the total number and nucleation mode concentrations of sulphate aerosol particles along the Sagar Kanya cruise routes of IFP-99. Observations are from Kamra et al. (2003) and are decreased by $30 \%$ for the sake of comparing with sulphate only modelled number concentrations.

\subsubsection{Sulphate number concentration}

Figure 6 illustrates the modelled and observed nucleation and total number concentrations along the Sagar Kanya cruise routes of IFP-99. The Kamra et al. (2003) observations show that more than $70 \%$ of the submicron aerosols advecting off 
the continent consists of sulphate aerosols and for this reason we report $70 \%$ of their concentrations for the sake of comparing with the sulphate only modelled concentrations.

In general, a strong northeasterly flow has been observed over the Indian continent in February and March 1999 leading to a greater transport of atmospheric pollutants over oceanic regions downwind of source regions (Verver et al., 2001; Rasch et al., 2001). The simulated wind pattern in Fig. 13 depicts the above fact very well with a strong northeasterly flow and anti-cyclonic motion near the oceanic regions resulting in higher number concentrations in northern cruise track. The model simulates the order of magnitude and the general north-south gradient feature in aerosol number concentrations very well. The feature is thus in general agreement with the transport pattern prevalent over the region (Fig. 13).

\subsubsection{Sulphate mass concentration and AOD at KCO}

\subsection{Latitudinal variations}

The latitudinal variation of sulphate number concentration and AOD in the Arabian Sea and Bay of Bengal for each month is discussed in this section. The latitudinal variations are obtained by separately averaging the values of a variable in the longitude ranges $60-80^{\circ} \mathrm{E}$ (Arabian Sea - Indian Ocean sector) and $80-100^{\circ} \mathrm{E}$ (Bay of Bengal - Indian Ocean sector).

\subsubsection{Sulphate aerosol number concentration}

Figure 7 presents latitudinal variations in the sulphate aerosol number distribution during IFP-99 over the Arabian Sea and Bay of Bengal sectors. One of the important features noted here is that much lower concentrations are observed south of the Intertropical Convergence Zone (ITCZ). Latitudinal variations in the Arabian Sea sector of the Aitken mode concentration (Fig. 7a) show a peak around $10-15^{\circ} \mathrm{N}$ region with a value of $8 \times 10^{3}$ particles $\mathrm{cm}^{-3}$ while in the Bay of Bengal sector the peak occurs around $25-30^{\circ} \mathrm{N}$ region with a maximum of $6.5 \times 10^{3}$ particles $\mathrm{cm}^{-3}$, which decreases to the order of about $3 \times 10^{3}$ particles $\mathrm{cm}^{-3}$ upon reaching $5^{\circ} \mathrm{S}$. This result is consistent with the finding of Lelieveld et al. (2001) who also reported a drastic decrease in sulphate aerosols on crossing the ITCZ from north to south. The latitudinal variations of the accumulation mode concentration (Fig. 7b) show a larger magnitude over the Arabian Sea sector than the Bay of Bengal sector with elevated values in the interval $10-25^{\circ} \mathrm{N}$. This indicates a strong influence of continental aerosols in the marine boundary layer over the Arabian Sea. The model predicts large aerosol concentrations ranging between $10^{2}$ and $10^{3}$ particles $\mathrm{cm}^{-3}$ over the North Indian Ocean during IFP and the contribution of Aitken mode concentration along north of ITCZ is significantly higher than that of the accumulation mode. These results generally agree
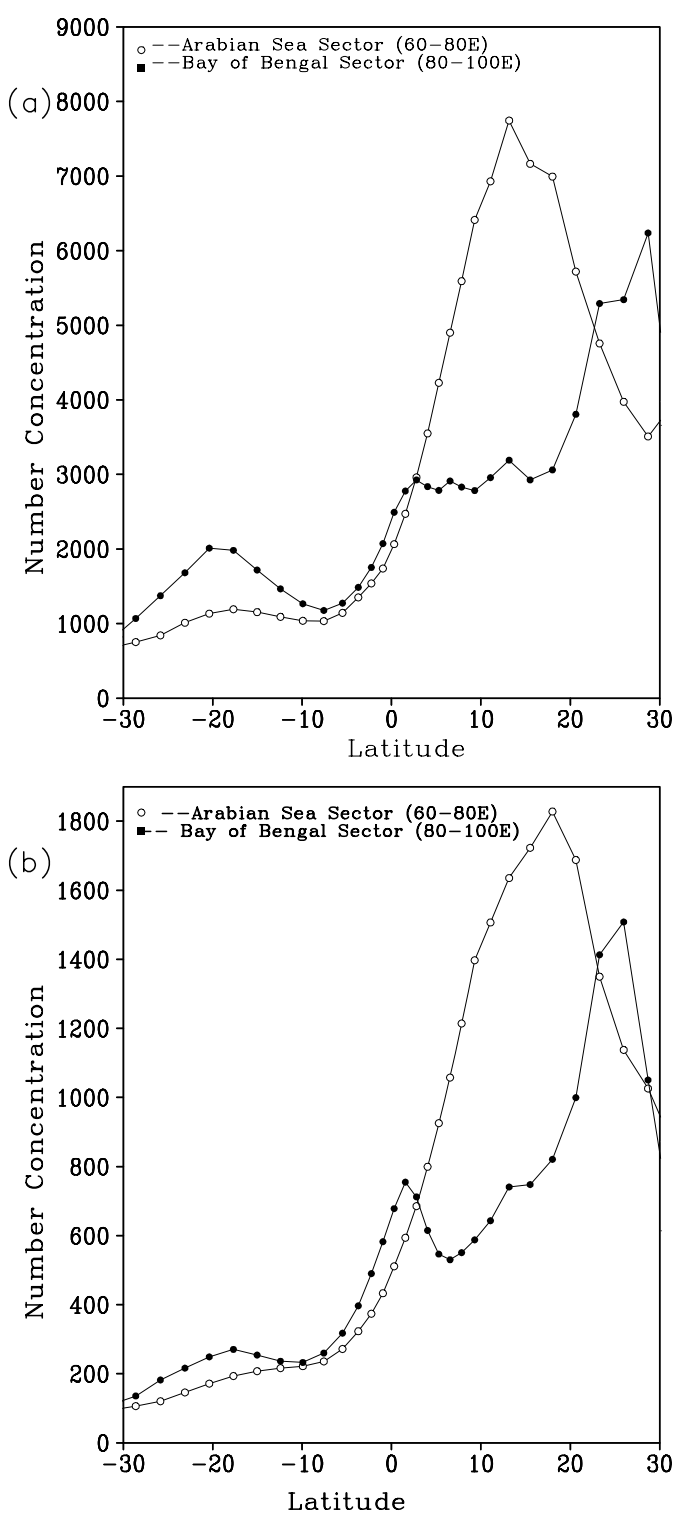

Fig. 7. Latitudinal variation of sulphate number concentration (particle $\mathrm{cm}^{-3}$ ) in the (a) Aitken and (b) accumulation modes over the Bay of Bengal and Arabian Sea sectors.

with those of Lelieveld et al. (2001) and Kamra et al. (2003) who showed that the large number concentration during the IFP mostly consists of particles in the Aitken mode. The simulated aerosol number concentration very well illustrates that the average aerosol concentration over the Northern Hemisphere is much larger than the southern Indian ocean (Kamra et al., 2003).

An observation on the number concentration and mass in the two modes is interesting. For example, the number concentration in the Aitken mode over the Arabian sea reaches a peak value of $8 \times 10^{3}$ particles $\mathrm{cm}^{-3}$ with the corresponding mass of $0.6 \mu \mathrm{g} \mathrm{m}^{-3}$. On the contrary the number 
concentration in the accumulation mode reaches a maximum value of 1800 particles $\mathrm{cm}^{-3}$ and the corresponding mass there is about $4.6 \mu \mathrm{g} \mathrm{m}^{-3}$. This result is consistent with other studies, which have mentioned that most of the sulphate mass resides in the accumulation mode (Binkowski and Roselle, 2003).

\subsubsection{Sulphate AOD}

Figure 8 shows the latitudinal variations of aerosol optical depth during January, February and March 1999. The AOD is significantly larger in the Northern Hemisphere compared to the Southern Hemisphere during all three months, with maximum AOD near the continents. The latitudinal variation of sulphate AOD over the Arabian Sea sector (Fig. 8a) with Reddy and Venkataraman (RV) inventory shows a highest value $(0.12)$ at around $25^{\circ} \mathrm{N}$. A secondary peak is also observed at $10^{\circ} \mathrm{N}$ during the months of February and March. While in GEIA (Fig. 8c), latitudinal sulphate aerosol AOD is larger over $\left(10-15^{\circ} \mathrm{N}\right)$, minimum in ITCZ and noticeably rises over the southern Indian Ocean $\left(0-5^{\circ} \mathrm{S}\right)$ which then decreases linearly further southwards. The highest AOD is simulated in the month of February with a value of 0.08 close to Arabia and the west coast of India. The plume extends from $15^{\circ} \mathrm{N}$ to $5^{\circ} \mathrm{S}$ in the month of January and March with highest values of 0.06 and 0.08 respectively. Over the Bay of Bengal sector (Fig. 8b) AOD is generally comparable to that over the Arabian Sea with superior values during January. For all three months, a plume lies in the region 20 $25^{\circ} \mathrm{N}$ while another plume is also visible at $0-5^{\circ} \mathrm{S}$ region. The general features revealed by Fig. 8 are as follows: (i) the results show a southward migration of the AOD minimum in consonance with the migration of the ITCZ; (ii) there is a visible rise in sulphate AOD in the Arabian Sea sector over $0-10^{\circ} \mathrm{S}$ region with the Indian inventory (RV) suggesting the role of Indian emissions in these concentrations; (iii) the AOD in the Northern Hemisphere is larger than that of Southern Hemisphere by about 30-50\%. These patterns derived from model-simulated values are mostly confirmed by satellite observed patterns especially the maxima over 10$25^{\circ} \mathrm{N}$ regions (Chowdhury et al., 2001; Quinn et al., 2002; Reddy et al., 2004).

\subsection{Regional distribution for INDOEX-IFP}

The equatorial Indian Ocean region provides a unique opportunity to observe anthropogenic sulphate effects. From January to April, the predominant circulation in this region consists of a low-level flow from the northeast (Krishnamurti et al., 1998). This NE monsoon (Asian winter monsoon) should facilitate the formation and transport of new sulphate particles to oceanic regions far away from urban centres. The above feature is very crucial as atmospheric circulation and aerosol lifetimes are the dominant factors controlling both (a)

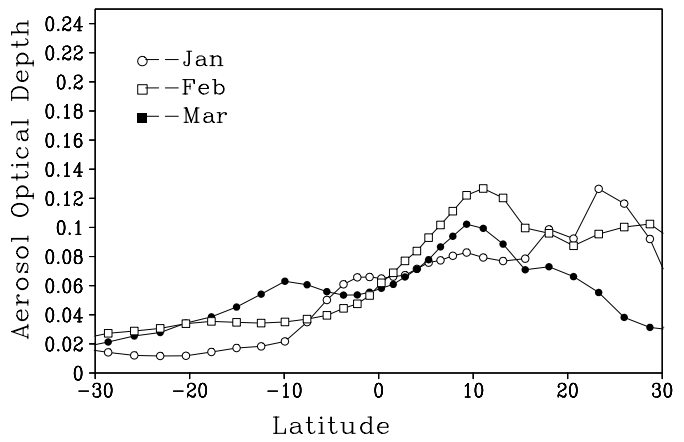

(b)

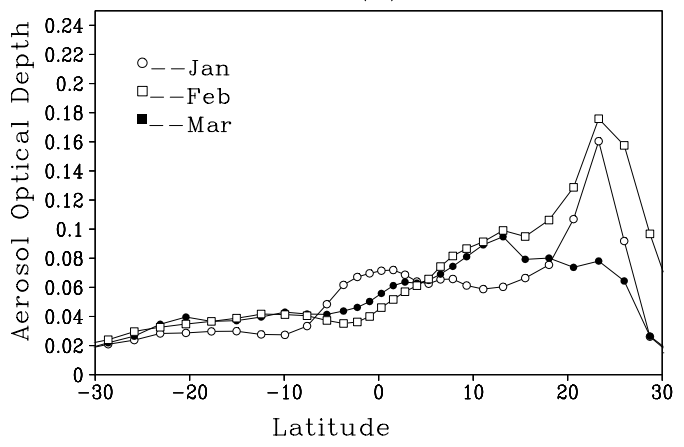

(c)

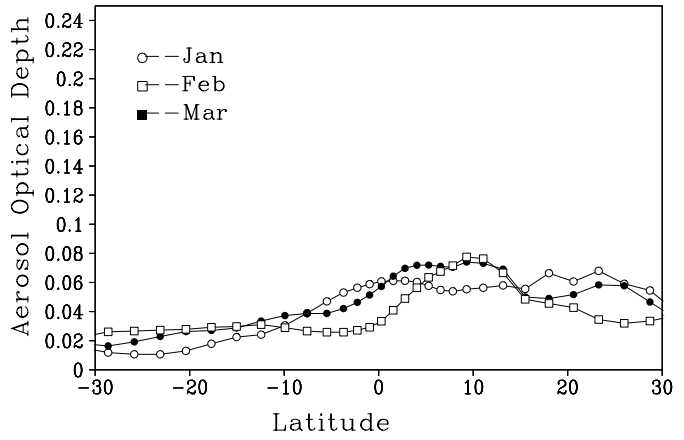

(d)

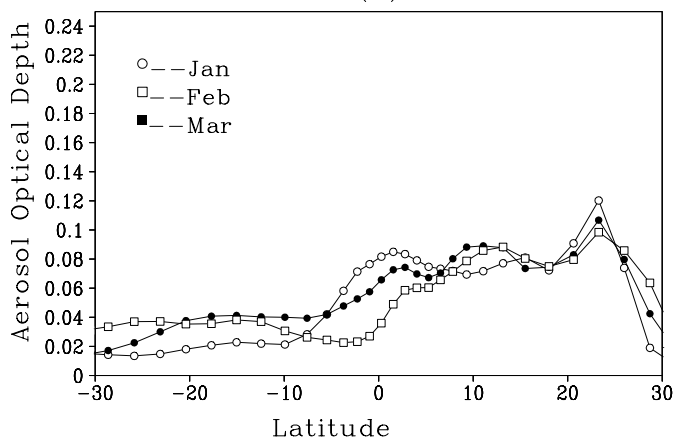

Fig. 8. Latitudinal variations of simulated sulphate AOD. (a) and (c) Arabian Sea sector $\left(60-80^{\circ}\right.$ E), (b) and (d) Bay of Bengal sector $\left(80-100^{\circ} \mathrm{E}\right)$. (a) and (b) are obtained from SCN-RV while (c) and (d) are from SCN-GEIA. 
(a)

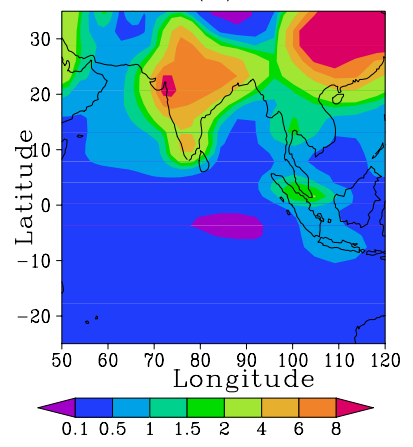

(b)

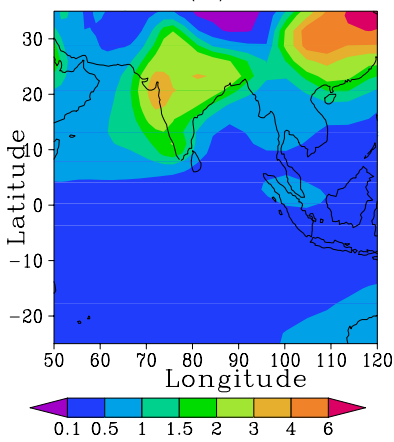

Fig. 9. Average $\mathrm{SO}_{2}$ distribution for January to March 1999 for the INDOEX domain: (a) surface concentration $\left(\mu \mathrm{S} \mathrm{SO}_{2} \mathrm{~m}^{-3}\right)$; (b) column burden $\left(\mathrm{mg} \mathrm{S} \mathrm{m}^{-2}\right)$.

(a)

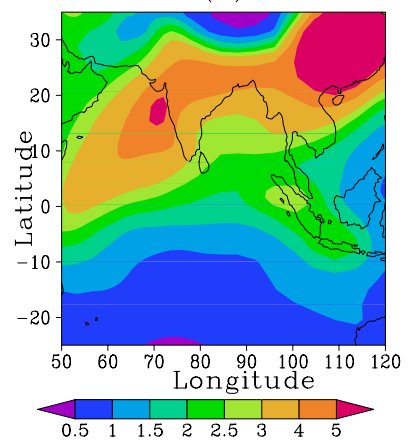

(b)

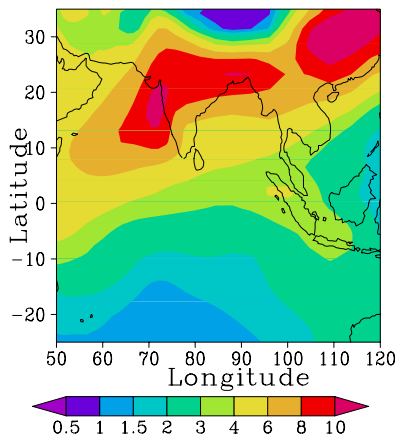

Fig. 10. Average sulphate distribution for January to March 1999 over the INDOEX domain: (a) surface concentration $\left(\mu \mathrm{SO}_{4}^{2-} \mathrm{m}^{-3}\right)$; (b) sulphate column burden $\left(\mathrm{mg} \mathrm{SO}_{4}^{2-} \mathrm{m}^{-2}\right)$.

spatial distribution and transport of aerosols that could be evaluated through a chemistry-transport model.

\subsection{1 $\mathrm{SO}_{2}$ concentration}

The model simulated spatial distribution of $\mathrm{SO}_{2}$ concentration over surface and column burden are shown (Fig. 9) over the INDOEX domain averaged for January, February and March 1999. The largest values at surface are found over southeastern China, western and eastern parts of India (8$10 \mu \mathrm{g} \mathrm{m}^{-3}$ ). Concentrations of $\mathrm{SO}_{2}$ over ocean are low indicating the short chemical lifetime.

\subsubsection{Sulphate mass and number concentrations}

The average surface concentrations (Fig. 10a) over SE China $\left(>5 \mu \mathrm{g} \mathrm{SO}_{4}^{2-} \mathrm{m}^{-3}\right)$ are higher than over India (3$4 \mu \mathrm{g} \mathrm{SO}{ }_{4}^{2-} \mathrm{m}^{-3}$ ) with elevated values $4-5 \mu \mathrm{g} \mathrm{m}^{-3}$ over northeast India. The plume extends over the Arabian Sea (2-3 $\left.\mu \mathrm{gSO}_{4}^{2-} \mathrm{m}^{-3}\right)$, the Bay of Bengal $\left(1-3 \mu \mathrm{g} \mathrm{SO}_{4}^{2-} \mathrm{m}^{-3}\right)$ and the Northern Indian Ocean $\left(0.5-2 \mu \mathrm{g} \mathrm{S}_{4}^{2-} \mathrm{m}^{-3}\right)$ indicating

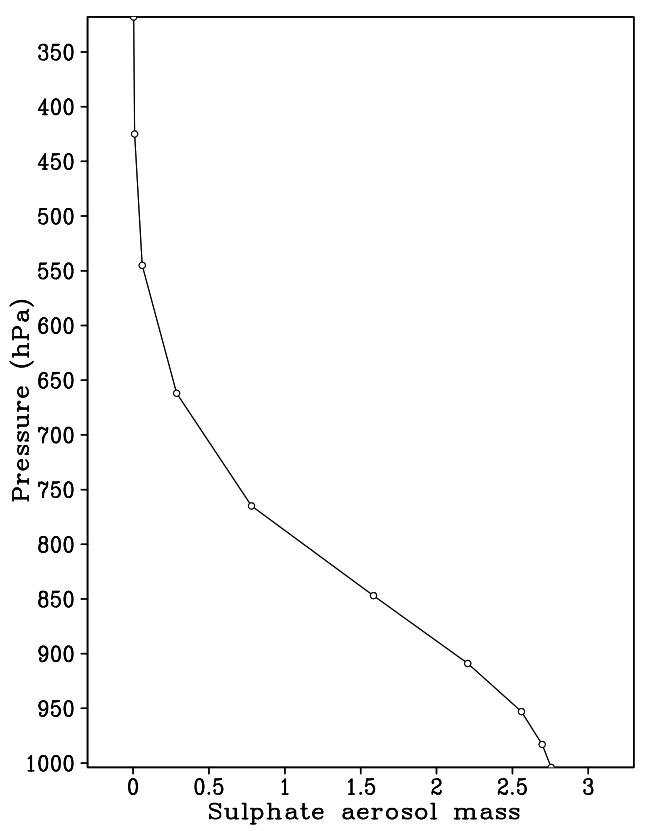

Fig. 11. Averaged vertical profile of sulphate aerosol mass $\left(\mu \mathrm{g} \mathrm{m}^{-3}\right)$ over the entire INDOEX region for the IFP. (a)

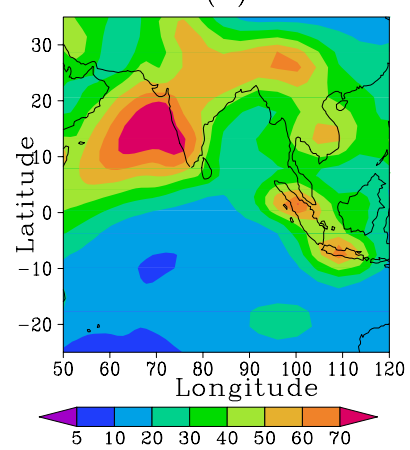

(b)

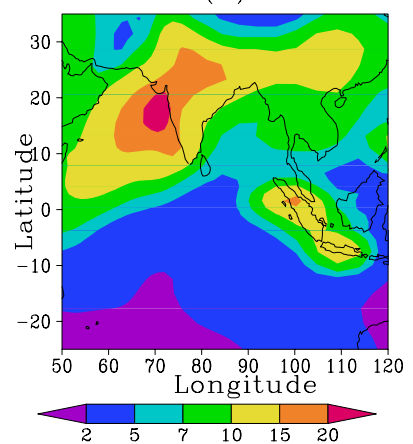

Fig. 12. Spatial distribution of particle number concentration (divided by 100) for January to March at surface in (a) Aitken mode and (b) accumulation mode concentration (particle $\mathrm{cm}^{-3}$ ).

advection of sulphate from continents to ocean. The sulphate column burden (Fig. 10b) show a high over south and east India $\left(8-10 \mathrm{mg} \mathrm{SO}{ }_{4}^{2-} \mathrm{m}^{-2}\right)$. The average vertical profile of sulphate aerosol loading (Fig. 11) shows a constant concentration up to a level of about $900 \mathrm{hPa}$ and then a substantial decrease by at least a factor of 2 at about $3 \mathrm{~km}(700 \mathrm{hPa})$. Notably, the observations reported by Rasch et al. (2001) also support the simulated average sulphate concentration for the entire INDOEX region during IFP and are consistent with earlier modelling studies. The Aitken mode average concentration $\left(4 \times 10^{3}-6 \times 10^{3}\right.$ particles $\left.\mathrm{cm}^{-3}\right)$ over India (Fig. 12) is more than that of the accumulation mode $\left(1 \times 10^{3}-2 \times 10^{3}\right.$ particles $\left.\mathrm{cm}^{-3}\right)$ with a maximum over 
(a)

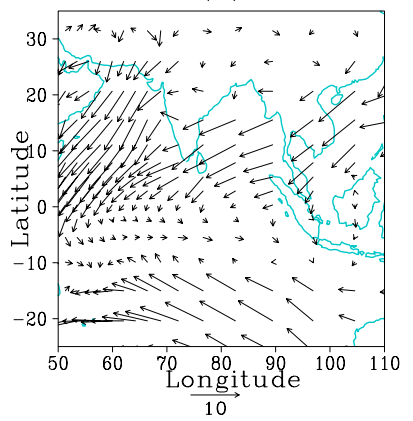

(b)

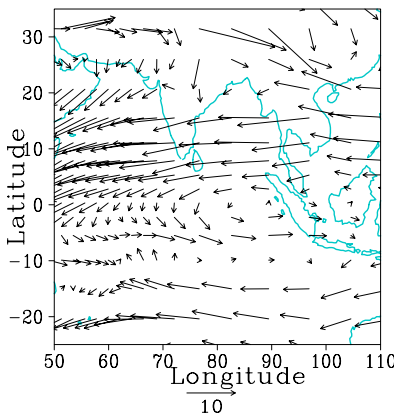

Fig. 13. Average wind field for January to March 1999 over the INDOEX domain at (a) the surface and (b) $850 \mathrm{hPa}$ pressure level.

western India $\left(3 \times 10^{3}-4 \times 10^{3}\right.$ particles $\left.\mathrm{cm}^{-3}\right)$ extending to the Arabian Sea region in diminishing magnitudes. Since the precursor gases for the formation of these sub-micron particles come mostly from the continents, the model reveals SE China and Indian region as important contributors to anthropogenic sulphate aerosol production. The observed decrease in the concentration of particles in the accumulation mode from north to south is due to the removal of these particles by dry and wet deposition (Kamra et al., 2003). During winter, the near-surface flow is mostly northeasterly, and the regional pollution forms a thick haze layer in the lower troposphere which spreads out over millions of square $\mathrm{km}$ between southern Asia and the Intertropical Convergence Zone (ITCZ), located several degrees south of the equator over the Indian Ocean during this period (Lawrence and Lelieveld, 2010). Wind vectors at the surface (Fig. 13a) also show strong outflows from north and east India into the Arabian Sea and Northern Indian Ocean. These strong flows explain the plausible cause of advection of $\mathrm{SO}_{2}$ and sulphate from continents and contribute to sulphate column burden over oceanic regions.

\subsubsection{Sulphate AOD and its radiative properties}

In Fig. 14a, the geographical distribution of the sulphate aerosol optical depth during the INDOEX period is presented. The largest values in AOD lie over SE China where the anthropogenic source of sulphur is very intense. An area of large AOD (0.1-0.14) and radiative forcing at top of atmosphere $\left(-1.25\right.$ to $-2.0 \mathrm{~W} \mathrm{~m}^{-2}$ ) is observed (Fig. 14b) from this region covering India: AOD over northern India (0.040.1 ) extends deep into the Arabian Sea and the Indian Ocean region (down to $10^{\circ} \mathrm{S}$ ). Higher AOD values are also noted over southeastern part of India with a maximum reaching 0.12. From coast to the central Bay of Bengal lower values of AOD occur where aerosol transport, both from India and South-East Asia, is insignificant and reflects the impact of anticyclonic circulation near South India (Rajeev et al., 2000), which does not allow the offshore flow from eastern India (a)

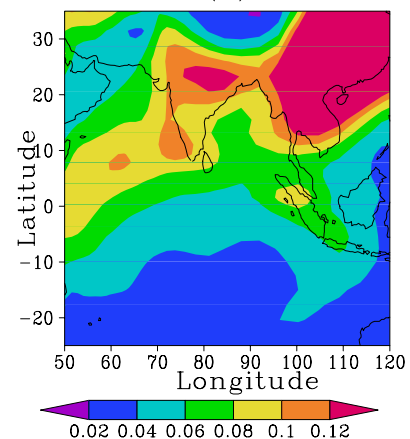

(b)

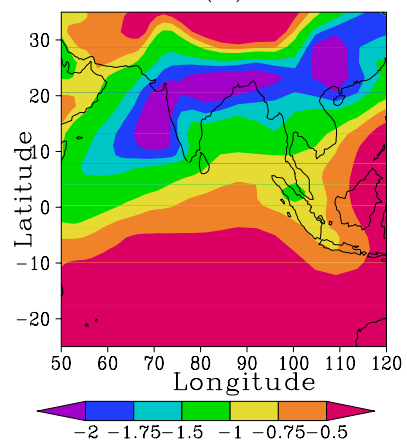

Fig. 14. (a) Sulphate aerosol optical depth during INDOEXIFP, and (b) direct sulphate radiative forcing at top of atmosphere $\left(\mathrm{W} \mathrm{m}^{-2}\right.$ ). (a)

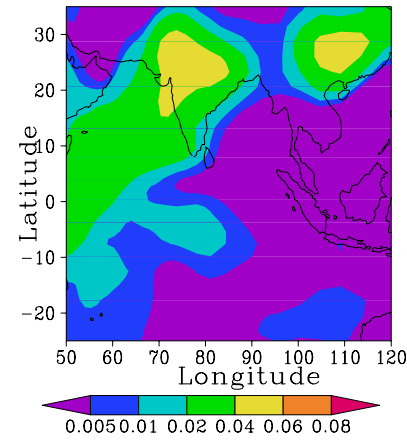

(b)

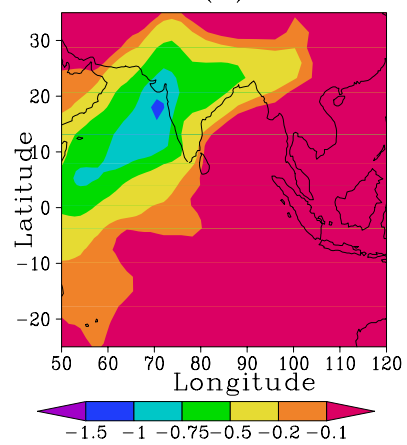

Fig. 15. Simulated differences from the use of two inventories (a) Sulphate aerosol optical depth during INDOEX-IFP, and (b) direct sulphate radiative forcing at top of atmosphere $\left(\mathrm{W} \mathrm{m}^{-2}\right)$.

to penetrate deep into the Bay of Bengal. Smaller magnitudes of radiative forcing $\left(<0.75 \mathrm{~W} \mathrm{~m}^{-2}\right)$ and $\mathrm{AOD}(<0.04)$ are present southwards to $5^{\circ} \mathrm{S}$, near the ITCZ (Quinn et al., 2002).

In order to assess the role of Indian emissions in increased pollution levels, we emphasize and show the differences obtained in the radiative forcing and AOD (Fig. 15) by the two inventories. Our result indicates that Indian emission does contribute significantly to the AOD and radiative forcing over the Arabian Sea while there is meagre to very small contribution over the Bay of Bengal.

\subsection{Indian source contribution to sulphate burden}

The Indian emissions are carried deep down into the Arabian Sea sector and to the coastal Bay of Bengal region. Thus the air from India contributes more strongly to Arabian Sea and to the near coastal region of Bay of Bengal. The large aerosol plume off the southwest coast is particularly noticeable (Fig. 16). There is a visible Asian plume entering at about $15-25^{\circ} \mathrm{N}, 90^{\circ} \mathrm{E}$, contributing significantly to sulphate 


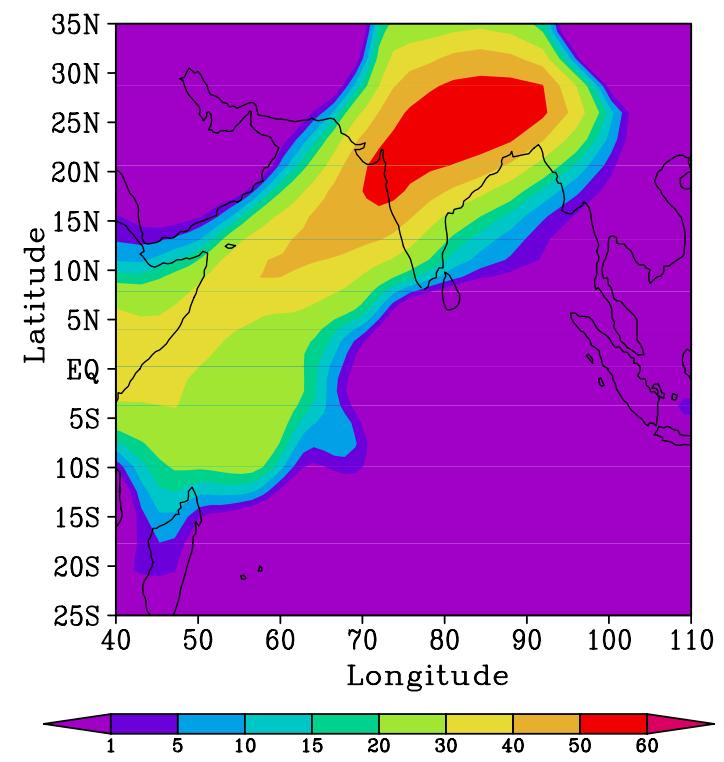

Fig. 16. Contribution (\%) of the Indian sources to sulphate burden over the INDOEX region during the IFP.

burden. Atmospheric circulation and trajectory analysis for INDOEX region has shown large southwestward movement of air from peninsular India at lower tropospheric levels. As a consequence, a large amount of sulphate off the west coast of India has been transported over to oceanic regions. Over the Bay of Bengal region however, there is considerable movement of air from southeast Asia due to prevailing easterly and northeasterly winds (Krishnamurti et al., 1998; Rajeev et al., 2000; Rasch et al., 2001).

\section{Conclusions}

A fully interactive sulphur chemistry module has been used to simulate sulphate mass as well as number distribution as prognostic variables. The model simulates the sulphate AOD, mass and number concentration to acceptable levels for the entire INDOEX region during IFP. Modelled surface and vertical concentration fields show encouraging agreement in spatial patterns and temporal episodicity with comparable magnitudes of observed quantities. At Kaashidhoo, the model simulated sulphate values agree with observations within a factor of 2-3. The measured aerosol optical depth (AOD) from all aerosol species (of which sulphate constitutes $29 \%$ ) at KCO was $0.37 \pm 0.1$, while the model predicted sulphate AOD is in the range of 0.05 to 0.11 . Hence, the predicted values of sulphate AOD are fairly close to measured values, indicating the capability of the model to predict the vertically integrated column sulphate burden. In general, the plume of sulphate mass, number concentration and aerosol optical depth in the Northern Hemisphere is larger than that of Southern Hemisphere by $\sim 30-50 \%$, which fol- lows the migration of ITCZ with a minimum centred around this region.

In conclusion, Indian emissions are not the sole cause for the higher sulphate concentrations and AOD over the Indian Ocean. The Indian contribution is more than $60 \%$ over India and $30-50 \%$ over the Arabian Sea. The aerosols transported from the East Asia contribute significantly to sulphate burden over the Bay of Bengal. Transport of aerosol by northwesterly winds from Arabia and northeasterly winds from the Indian subcontinent are the major sources of higher concentrations over the Arabian Sea; whereas over the Bay of Bengal, the transport is mainly from Southeast Asia.

Acknowledgements. The authors would like to thank the editor and anonymous reviewers for their insightful comments that were helpful in improving substantially the presentation and contents of the revised manuscript. This work was supported by the IndoFrench Centre for the Promotion of Advanced Research/Centre Franco-Indien Pour la Recherche Avancée under project 1911-2.

Edited by: U. Lohmann

\section{References}

Andronache, C., Donner, L. J., Seman, C. J., and Hemler, R. S.: A study of the impact of ITCZ on aerosols during INDOEX, J. Geophys. Res., 107, 8027, doi:10.1029/2001JD900248, 2002.

Barth, M. C. and Church, A. T.: Regional and global distributions and lifetimes of sulfate aerosols from Mexico City and southeast China, J. Geophys. Res., 104, 30231-30239, 1995.

Binkowski, F. S. and Shankar, U.: The regional particulate matter model: Part 1, model description and preliminary results, J. Geophys. Res., 100, 26191-26209, 1995.

Binkowski, F. S. and Roselle., S. J.: Models-3 community multiscale air quality (CMAQ) model aerosol component 1. model description, J. Geophys. Res., 108, 4183, doi:10.1029/2001JD001409, 2003.

Boer, G. J.: Some results from an intercomparison of the climates simulated by 14 atmospheric general circulation models, J. Geophys. Res., 97, 12771-12786, 1992.

Boucher, O. and Lohmann, U.: The sulfate-CCN-cloud albedo effect: a sensitivity study using two general circulation models, Tellus, 47B, 281-300, 1995.

Boucher, O., Pham, M., and Sadourny, R.: General circulation model simulation of of Indian summer monsoon with increasing levels of sulphate aerosols, Annales Geophysicae, 16, 346-352, 1998.

Boucher, O., Pham, M., and Venkataraman, C.: Simulation of the atmospheric sulphur cycle in the Laboratoire de Météorologie Dynamique general circulation model: Model description, model evaluation, and global and European budgets, Note scientifique de l'IPSL no. 23, 2002.

Cess, R. D., Potter, G. L., Blanchet, J. P., Boer, G. J., Ghan, S. J., Kiehl, J. T., Le Treut, H., Li, Z.-X., Liang, X.-Z., Mitchell, J. F. B., Morcrette, J.-J., Randall, D. A., Riches, M. R., Roeckner, E., Schlese, U., Slingo, A., Taylor, K. E., Washington, W. M., Wetherald, R. T., and Yagai, I.: Interpretation of cloud- 
climate feedback as produced by 14 atmospheric general circulation models, Science, 245, 513-516, 1989.

Charlson, R. J., Schwartz, S. E., Hales J. M., Cess, R. D., Coakley, J. A., Hansen, J. E., and Hotmann, D. J.: Climate forcing by anthropogenic aerosols, Science 255, 423-430, 1992.

Chen, J.-P. and Crutzen, P. J.: Solute effect on the evaporation of ice particles, J. Geophys. Res., 99, 18847-18859, 1994.

Chowdhury, Z., Hughes, L. S., and Salmon, L. G.: Atmospheric particle size an composition measurements to support light extinction calculation over the Indian Ocean, J. Geophys. Res., 106, 28597-28605, 2001.

de Gouw, J. A., Warneke, C., Scheeren, H. A., van der Veen, C., and Bolder, M.: Overview of the trace gas measurements on board the Citation aircraft during the intensive field phase of INDOEX, J. Geophys. Res., 106, 28453-28467, 2001.

Giorgi, F. and Chameides, W. L.: Rainout lifetimes of highly soluble aerosols and gases as inferred from simulations with a general circulation model, J. Geophys. Res., 91, 14367-14376, 1986.

Hauglustaine, D. A., Hourdin, F., Jourdain, L., Filiberti, M.A., Walters, S., Lamarque, J.-F., and Holland, E. A.: Interactive chemistry in the Laboratoire de Météorologie Dynamique general circulation model: description and background tropospheric chemistry evaluation, J. Geophys. Res., 109, D04314, doi:10.1029/2003JD003957, 2004.

Hourdin, F. and Armengaud, A.: On the use of finite volume methods for atmospheric advection of trace species: I. Test of various formulations in a general circulation model, Mon. Weather Rev., 127, 822-837, 1999.

Kamra, A. K., Murugavel, P., and Pawar, S. D.: Measured size distributions of aerosols over the Indian Ocean during INDOEX, J. Geophys. Res., 108, 8000, doi:10.1029/2002JD002200, 2003.

Kiehl, J. T. and Briegleb, B. P.: The relative role of sulphate aerosols and greenhouse gases in climate forcing, Science, 260, 311-314, 1993.

Krishnamurti, T. N., Jha, B., Prospero, J. M., Jayaraman, A., and Ramanathan, V.: Aerosol and pollutant transport and their impact on radiative forcing over tropical Indian Ocean during January-February 1996 pre-INDOEX cruise, Tellus B, 50, 521542, 1998.

Lawrence, M. G., Crutzen, P. J., Rasch, P. J., Eaton, B. E., and Mahowald, M.: A model for studies of tropospheric chemistry: Description, global distributions, and evaluation, J. Geophys. Res., 104, 26245-26277, 1999.

Lawrence, M. G. and Lelieveld, J.: Atmospheric pollutant outflow from southern Asia: a review, Atmos. Chem. Phys., 10, 1101711096, doi:10.5194/acp-10-11017-2010, 2010.

Lelieveld, J., Crutzen, P. J., Ramanathan, V., Andreae, M. O., Brenninkmeijer, C. A. M., Campos, T., Cass, G. R., Dickerson, R. R., Fischer, H., de Gouw, J. A., Hansel, A., Jefferson, A., Kley, D., de Laat, A. T. J., Lal, S., Lawrence, M. G., Lobert, J. M., MayolBracero, O., Mitra, A. P., Novakov, T., Olmans, S. J., Prather, K. A., Reiner, T., Rodhe, H., Scheren, H. A., Sikka, D., and Williams, J.: The Indian Ocean Experiment: Widespread air pollution from south and southeast Asia, Science, 291, 1031-1035, 2001.

Le Treut, H., Li, Z. X., and Forichon, M.: Sensitivity study of LMD GCM to greenhouse forcing associated with two different cloud water parametrization, J. Climate, 7, 1827-1841, 1994.
Li, Z. X.: Ensemble atmospheric GCM simulation of climate interannual variability from 1979 to 1994, J. Climate, 12, 986-1001, 1999.

Lott, F.: Alleviation of stationary bias in a GCM through a mountain drag parametrization scheme and a simple representation of mountain lift forces, Mon. Weather Rev., 127, 788-801, 1999.

Mallet, M., Roger, J. C., Depiau, S., Putaud, J. P., and Dubovik. O.: A study of the mixing state of black carbon in urban zone, J. Geophys. Res., 109, D0402, doi:10.1029/2003JD003940, 2004.

Ohta, S., Okita, T., and Kato, C., A numerical model of acidification of cloud water, J. Meteor. Soc. Japan, 6, 59, 1981.

Pham, M., Muller, J.-F., Brasseur, G., Granier, C., and Mégie, G.: A 3-D model study of the global sulphur cycle: Contributions of anthropogenic and biogenic sources, Atmos. Environ., 30, 1815$1822,1995$.

Quinn, P. K., Coffman, D. J., Bates, T. S., Miller, T. L., Johnson, J. E., Welton, E. J., Neususs, C., Miller, M., and Sheridan, P. J.: Aerosol optical properties during INDOEX-1999: Means, variability, and controlling factors, J. Geophys. Res., 107, 8020, doi:10.1029/2000JD000037, 2002.

Rajeev, K., Ramanathan, V., and Maywerk, J.: Regional aerosol distribution and its long range transport over the Indian Ocean, J. Geophys. Res., 105, 2029-2043, 2000.

Ramanathan, V., Crutzen, P. J., Lelieveld, J., Althausen, D., Anderson, J., Andreae, M. O., Cantrell, W., Cass, G., Chung, C. E., Clarke, A. D., Collins, W. D., Coakley, J. A., Dulac, F., Heintzenberg, J., Heymsfield, A. J., Holben, B., Hudson, J., Jayaraman, A., Kiehl, J. T., Krishnamurti, T. N., Lubin, D., Mitra, A. P., MacFarquhar, G., Novakov, T., Ogren, J. A., Podgorny, I. A., Prather, K., Prospero, J. M., Priestley, K., Quinn, P. K., Rajeev, K., Rasch, P.,Rupert, S., Sadourny, R., Satheesh, S. K., Sheridan, P., Shaw, G. E., and Valero, F. P. J.: The Indian Ocean Experiment: An integrated analysis of the climate forcing and effects of the great Indo-Asian haze, J. Geophys. Res., 106, 28371-28398, 2001.

Rasch, P. J., Barth, M. C., Kiehl, J. T., Schwartz, S. E., and Benkowitz, C. M.: A description of the global sulphur cycle and its cotrolling processes in the National Centre for Atmospheric Research Community Climate Model, Version 3, J. Geophys. Res., 105, 1367-1385, 2000.

Rasch P. J., Collins, W. D., and Eaton, B. E.: Understanding the Indian Ocean experiment aerosol distribution with an aerosol assimilation, J. Geophys. Res., 106, 28371-28398, 2001.

Reddy, M. S. and Venkataraman, C.: Inventory of aerosol and sulphur dioxide emissions from India: I - Biomass combustion, Atmos. Environ., 36, 677-697, 2002a.

Reddy, M. S. and Venkataraman, C.: Inventory of aerosol and sulphur dioxide emissions from India: II - Biomass combustion, Atmos. Environ., 36, 699-712, 2002 b.

Reddy, M. S., Boucher, O., Venkataraman, C., Verma, S., Léon, J.F., Bellouin, N., and Pham, M.: GCM estimates of aerosol transport and radiative forcing during INDOEX, J. Geophys. Res., 109, D16205, doi:10.1029/2004JD004557, 2004.

Sadourny, R. and Laval, K.: January and July performances of LMD general circulation model. New perspectives in Climate Modelling, edited by: Berger, A., Elsevier, 173-198, 1984.

Satheesh, S. K., Ramanathan, V., Jones, X., Lobert, J. M., Podgorny, I. H., Prospero, J. M., Holben, B. N., and Loeb, N. G.: A model for the natural and anthropogenic aerosols over the tropical Indian Ocean derived from Indian Ocean Experiment data, J. Geo- 
phys. Res., 104, 27421-27440, 1999.

Satheesh, S. K. and Ramanathan, V.: Large differences in tropical aerosol forcing at the top of the atmosphere and Earth's surface, Nature, 405, 60-63, 2000.

Schwartz, S. E.: Mass-transport considerations pertinent to aqueous-phase reactions of gases in liquid-water clouds, Chemistry of Multiphase Atmospheric Systems, edited by: Jaeschke, W., 415-471, Springer, New York, 1986.

Sharma, O. P., Le Treut, H., Sèze, G., Fairhead, L., and Sadourny, R.: Interannual variations of summer monsoons: Sensitivity to cloud radiative forcing, J. Climate, 11, 1883-1905, 1998.

Snider, J. R. and Vali, G.: Sulphur dioxide oxidation in winter orographic clouds, J. Geophys. Res., 99, 18713-18733, 1994.

Stier, P., Feichter, J., Kinne, S., Kloster, S., Vignati, E., Wilson, J., Ganzeveld, L., Tegen, I., Werner, M., Balkanski, Y., Schulz, M., Boucher, O., Minikin, A., and Petzold, A.: The aerosol-climate model ECHAM5-HAM, Atmos. Chem. Phys., 5, 1125-1156, doi:10.5194/acp-5-1125-2005, 2005.

Tiedtke, M.: A comprehensive mass flux scheme for cumulus parameterization in large scale models, Q. J. Roy. Meteor. Soc., 117, 1779-1800, 1989.

UNEP and $\mathrm{C}^{4}$ : The Asian brown cloud: climate and other environmental impacts UNEP, Nairobi, 2002.
Venkataraman, C., Mehra, V., and Mhaskar, P.: Mechanism of sulphate aerosol production in clouds: effect of cloud characteristic and season in the Indian region, Tellus, 53B, 260-272, 2001.

Verma, S., Boucher, O., Upadhyaya, H. C., and Sharma, O. P.: Sulfate aerosols forcing: An estimate using a three-dimensional interactive chemistry scheme, Atmos. Environ., 40, 7953-7962, doi:10.1016/j.atmosenv.2006.07.010, 2006.

Verma, S., Boucher, O., Reddy, M. S., Upadhyaya, H. C., Van Le, P., et al.: Modeling and analysis of aerosol processes in an interactive chemistry general circulation model, J. Geophys. Res., 112, D03207, doi:10.1029/2005JD006077, 2007.

Verver, G. H. L., Sikka, D. R., Lobert, J. M., Stossmeister, G., and Zachariasse, M.: Overview of the meteorological conditions and atmospheric transport during INDOEX 1999, J. Geophys. Res., 106, 28399-28414, 2001.

Vignati, E., Wilson, J., and Stier, P.: M7: An efficient size-resolved aerosol microphysics module for large-scale aerosol transport models, J. Geophys. Res., 109, D22202, doi:10.1029/2003JD004485, 2004.

Walcek, C. J. and Taylor, R.: A theoretical method for computing vertical distribution of acidity and sulfate production with cumulus clouds, J. Atmos. Sci., 43, 339-355, 1986. 